\title{
TECHNICAL AND TECHNOLOGICAL INNOVATIONS AND QUALITY IN ROAD TRANSPORT OF GOODS - SELECTED ASPECTS
}

\begin{abstract}
The article presents the results of research regarding the impact of technical and technological innovations on the quality of services in road transport of goods. The study was conducted using a structured questionnaire survey on a sample of 134 road transport companies. Respondents were managers and business owners. 7 factors, which potentially determined the quality of services, were assessed by the respondents. The data analysis used the arithmetic mean and the dominant, which formed the basis for determining the importance of a given factor for the quality of services. The variability analysis provided information about the variation of the sample. The results of the research proved the influence of innovation on quality. The highest-ranked factors supporting the quality of road transport services were intelligent transport systems, the ability to inform the customer about the actual location of the shipment (delivery time) and systems supporting the work of a professional driver. The article also identified selected innovations and attempts were made to determine their importance in the development of the quality of services and the effects of their functioning on the road transport system.
\end{abstract}

Keywords: transport, quality, services, innovations

JEL: L6, O18, R41

\section{Introduction}

The transport services market is a dynamic economic category. The changes taking place in the global economy and the progress of civilization determine the conditions for its functioning and the direction of development. The source 
of global change are the processes of liberalization and integration (Nijkamp, 2003). They were of particular importance in the group of Central and Eastern European countries where trade liberalization had a significant impact on their development (Kruk, Waśniewska, 2017).

Economic phenomena and processes determine the quantitative and qualitative diversity of market structures. The heterogeneity of the transport market also results from the functioning of substitutional (branch) and complementary markets. These, in turn, shape the volatility of the conditions and requirements for the provision of transport services. Regardless of the geographical differences between the place of sending and collection of cargo, the transport handles the needs of international trade. Effective execution of orders is possible thanks to the technical and technological development. They improve transport processes, deciding about the successful implementation of transport postulates. Innovative techniques and technologies determine the activities of carriers, but also the systems in which they operate. Therefore, a holistic approach to considering the pro-quality development of road transport seems justified.

In providing high-quality services, it is crucial to understand the needs of customers. Definitions of quality indicate the importance of the customers in shaping the offer, satisfying or anticipating their needs. In road cargo transport, the quality of services is often determined through the prism of broadly understood attributes of punctuality and security of supply. The subject of negotiations between the seller and the purchaser of services is to determine the conditions (and quality) of their provision. Table 1 presents classifications of the quality features of transport services. Attention should be paid to the degree of diversity and refinement of these properties. A particular feature may be an aggregate of several or may be conditioned by the existence of another feature.

Table 1. Classification of quality features in transport

\begin{tabular}{|l|l|}
\hline \multicolumn{1}{|c|}{ Author } & \multicolumn{1}{c|}{ Quality features } \\
\hline S. Klatt & $\begin{array}{l}\text { 1. Spatial distance: ubiquity, mobility, flexibility available in space, freedom } \\
\text { of movement of transport means, directness of transport, ability to create networks, } \\
\text { dependence on the conditions of nature, the ability to create branching, continuity } \\
\text { of the transport network. }\end{array}$ \\
2. Subject of freight: universality, specialization (adaptation to the requirements \\
of the subject of freight), flexibility to adapt to the requirements of various subjects \\
of freight, the ability to increase the size of services, mass, diligence, transport \\
safety, utility. \\
3ime: reliability, certainty, flexibility of access in time, distribution, frequency, \\
planning, precision, punctuality, regularity, speed.
\end{tabular}

Source: (Tarski, 1976) 
Delivery in accordance with the indicated characteristics, reflecting the preferences and transport postulates depends on endogenous and exogenous factors. Their importance for quality is indicated by Gea et al. (nd). The use of modern techniques and technologies (innovations) in transport processes can be an example of a pro-quality development of carriers. It includes, among others, modern rolling stock and positioning systems. Quality development in transport can be institutionally supported. Investments in trans-European transport corridors (linear and point infrastructure), EU countries' commitment to creating a coherent system are examples of good practices. They result in increased access to high-quality transport services as well as improvement of the quality of life of societies (Melecký, 2018). In addition, Janelle and Beuthe (1997) emphasize the importance of the development of information and communication networks as the basic determinants of the development of modern transport systems.

The article points to the importance of technical and technological innovations in road transport of goods. The thesis on the stimulating influence of technical and technological innovations on the quality of transport services was established. The aim of the research was to classify technical and technological innovations and to determine their importance in shaping the quality of road freight transport. An attempt was also made to identify relations of cause and effect nature between the quality of services and technical and technological innovations and the potential direction of their development.

\section{Methodology and theory}

The impact of technical and technological innovations on the quality of services in road transport of goods was analyzed in two aspects: empirical and theoretical. The purpose of primary research was to determine the importance of modern technical and technological solutions for the quality of transport services. The aim of the literature studies was to indicate the potential direction of innovation development and to determine their impact on quality in the road freight transport sector.

The basic instrument for obtaining primary data was an interview using a questionnaire. The respondents were Polish road carriers whose activity was registered in the Warmian-Masurian Voivodeship, providing services in international cargo transport. The survey was conducted in 2013 on a sample of 134 people who are owners and managers in enterprises.

Figure 1 presents the structure of respondents. Most of them were entities with many years of market experience (79\% started their activity before 2004). Equally important is the fact that most of them represented the micro-enterprise sector (determined by the size of employment and the number of vehicles at their disposal).

The structure of respondents was similar to the structure of road carriers from the Warmian-Masurian Voivodeship (98\% are microenterprises). It is estimated that the structure of road carriers in Poland is represented by the majority of entities in the micro and small enterprises sector (about 70\%). Considering the structural similarity, the results of the research can be generalized with the proviso that 
the research was carried out only in one province. In addition, the author is aware that conducting research in large companies could affect the results. Large entities of the TFL sector have a much larger capital, which would probably affect their perception of innovation and the need to invest in quality development.

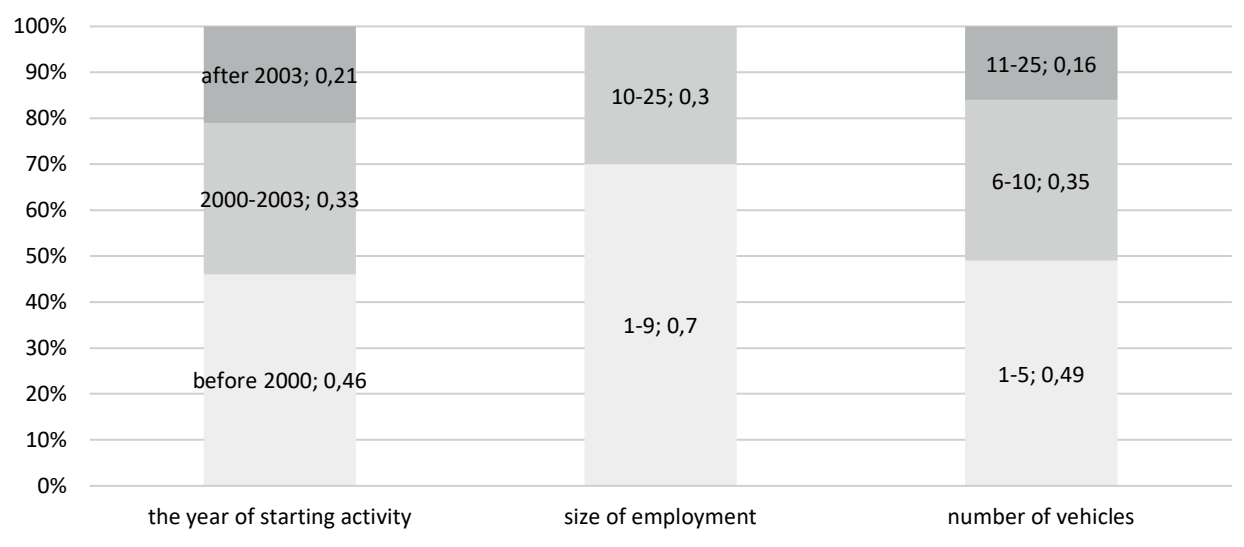

Figure 1 . The structure of respondents

Source: (based on the results of own research)

In empirical research, technical and technological innovations were determined by seven factors. They were established on the basis of preliminary interviews with owners and management staff of road transport companies. They include:

- systems improving driving (e.g. ABS, ASR, EBC, BAS, etc.),

- ergonomics and equipment of the driver's cab,

- technical standards of dimensions of vehicles,

- non-skid road surfaces,

- solar energy collectors used for heating asphalt,

- intelligent transport systems (GPS, Galileo, automatic information on accidents, congestion and diversion possibilities),

- informing the customer about the route, location of the shipment and delivery time.

They were subjected to the assessment of respondents in order to determine the importance of particular factors in shaping the quality of transport services. A six-grade scale of assessments was adopted (with a forced choice):

- 6 - it is very important

- 5 -it matters

- 4 -it quite matters,

- 3 - it quite does not matter,

- 2 -it does not matter

- 1 - it does not matter at all.

The factors whose average assessment was at the level $\geq 4$ were considered significant for the quality of services. The analysis of factors was carried out on the basis of location and volatility measures. The arithmetic mean and the dominant (D) were the basis for determining the importance of factors. The study was deepened 
by the analysis of variability ( $\mathrm{SD}$ - standard deviation, $\mathrm{R}$ - range, $\mathrm{V}$ - coefficient of variation), which provided information about the variation of the sample. The homogenous sample determines the coefficient of variation $(\mathrm{V})$ at a level of less than 10\% (Panek, Zwierzchowski, 2013).

The quality of services is most often considered from the perspective of purchasers. Obtaining customer satisfaction is the primary goal of business operations according to the TQM (Total Quality Management) philosophy. In the sphere of services, the relation between the quality perceived by the customer and the quality offered by enterprises is emphasized. They are defined as quality gaps that result from the difference between (Parasuraman et al., 1985):

- the expectations of the purchaser and the perception of these expectations by the service provider (gap 1),

- the perception of service users' expectations by the management staff and quality of service features (gap 2),

- the quality of service specification and the quality delivered (gap 3),

- the quality of the service and the information the customer received about it (gap 4),

- the expected and the delivered service (gap 5).

The result of the first four quality gaps is the fifth gap - the difference between what the customers expect and what they receive. Expectations are built on the basis of information acquired by marketing activities of service providers, own experience or experiences of other people in the form of the so-called word-of-mouth. The key factor reducing the fifth gap is understanding the factors that shape technical and functional quality and how they are perceived by the customer (Gronroos, 1984).

In this paper, the quality of services is analyzed from the perspective of service providers - market supply representatives. Quality studies from this perspective is rarely undertaken and few publications can be found in the literature on this subject. This approach was presented, for example, in research carried out by Lazauska et al. (2012). The results of their research allowed to indicate, among others, the basic attributes of the quality of services: quality of servicing and safety of transport.

Understanding the postulates and preferences of service recipients allows to create an offer in line with expectations. This information is conducive to minimizing the discrepancies between quality postulated by potential purchasers and the quality offered and given by carriers. Rudel (2005) points to the following quality attributes: time, punctuality, avoiding damages, which in the conditions of the Swiss market of TFL services are becoming increasingly important in the selection of the service provider. Research conducted among Czech customers showed that the most important factors in assessing the quality of services in road transport of cargo are: no damage in packaging, keeping delivery dates, no damage to transported goods, no accidents in transport processes (Koniecny, Stetinova, 2006). From the practice point of view, knowledge about quality attributes determines the direction of development and investments and determines the success rate of carriers decision making processes (Garver et al., 2010). The faster the operators' response to the specific customer requirements, the higher they will be assessed. Flexibility requires high organizational skills that can be supported by innovative solutions dedicated to the transport sector. 
Activity in commercial transport of goods does not belong to the high technology and innovation sector, as opposed to the electronics, telecommunications and chemical industry (Zemlickiene et al., 2018). In addition, road freight transport is the SME sector, which determines the possibilities of implementing innovations. Measures undertaken for the qualitative and quantitative development of resources through cooperation with other companies do not affect the possibilities of innovative development (Corral de Zubielqui et al., 2018). Innovation research often leads to establishing factors, patterns and trends in the development of enterprises or their tendency to innovate, including regional and sectoral analyses based on entrepreneurial surveys studies (Spitsin et al., 2018, Zygmunt, 2017, Gorączkowska, 2018). Cieślik and Michałek (2018) indicate positive relations between innovations and business efficiency. It seems that the institutional system support is also required for the development of innovation (Lewandowska, Stopa, 2018), especially in road freight transport.

The development of intelligent transport systems is important in terms of the quality of transport services. Szyc (2017) includes telematics (i.e. communication and IT technologies) supported by applications containing methods of control and management of transport systems and networks. In the qualitative development of road carriers and the whole branch sub-market, satellite navigation systems are of great importance. Global GPS positioning system (American military system) allows to indicate the location of objects equipped with special receivers with an accuracy of approximately 10 meters, determine the speed of vehicles and the direction of movement. The similar features characterize the Russian GLONASS system. Santerre et al. (2014) indicate that using the satellites of these two systems and supporting their operation with the Chinese BeiDou system can increase the precision in determining the position of vehicles up to 5 meters. Galileo is the European equivalent of the global positioning system. On the EU markets, its strong point is to be compatible and interoperable with existing (GPS, GLONASS) and planned satellite navigation systems.

Positioning systems and their functionality are of particular importance in shaping quality in road transport. They affect the safety of transport and time of delivery, regardless of whether they concern the so-called internet of things and location-based services, vehicle fleet management, protection in transport of specific goods or improving road safety and efficiency. Transport infrastructure that maximizes road safety is one of the strategic directions of its development (Burnewicz, 2012). It is important to ensure the safety of drivers, cargo and vehicles. A systematic approach to the qualitative development of transport systems requires the harmonization of technical terms of service providing. These include the technical dimensions of vehicles (e.g. length, width and height) and the conditions of use of the infrastructure (e.g. differentiation of provisions regarding permissible goods on the axles of the vehicle). The development of technology enabled the implementing of mega trucks (referred to as mega trucks, gigaliners and road trains) to handle the needs of European trade.

The Road Traffic Law Act precisely defines the dimensions of vehicles moving on Polish roads. Depending on the configuration of motor and non-motor rolling stock, vehicles cannot be longer than $18.75 \mathrm{~m}$ with a maximum gross weight not exceeding 44 tones (for intermodal transport). The current trend indicates 
the possibility of using larger vehicles - longer and with increased maximum gross weight. In Germany, $25.25 \mathrm{~m}$ long vehicles are allowed on the A3 motorway (Austria - Netherlands). In Denmark and the Netherlands, a truck with two center-axle trailers (they facilitate moving around intersections with circular movement) is used to handle transport needs. This set increases the possibility of creative use in distribution, because it is possible to attach standard swap bodies, each on a different chassis. In Finland, since January 2019, vehicles with a maximum length of $34.5 \mathrm{~m}$ and a maximum gross weight of 76 tons were allowed to move (in the coming years an increase of maximum gross weight to 100 tons is planned). These sets can carry two 40-feet containers. Undoubtedly, this determines the instrument of inter-branch competition, at the same time it provides for a new quality of services. Increasing the size of vehicles allows to shorten the waiting time for the execution of the order due to the increased production capacity of carriers.

In Sweden and Finland, there is no increased negative impact of mega trucks on road safety and the environment observed (compared to "traditional" vehicles). However, the situation may be different in other countries (Steer et al., 2013). It seems that for the quality of transport services it is crucial to adapt the infrastructure to the needs of vehicles with increased dimensions, additional training of drivers and improving the public awareness.

Modern technologies revolutionize motorization as well as vehicles used for commercial purposes. They are conducive to the increase of travel comfort and improve the driving technique. The driver's comfort is supported by the ergonomic shape of the cabin, providing quick and easy access to the functions used in vehicle traffic. The important elements supporting the drivers' comfort are the extensive functions of the seat adjustment, which also affect the speed of decisions and reaction in a road emergency. Systems affecting driving techniques are no less important in the safe provision of transport services. They include, among others Anti-Lock Braking System (ABS), Acceleration Slip Regulation (ASR), Electronic Braking System (ESP) and Brake Assist System (BAS).

Technological and technical innovations determine the safety of processes and the functioning of road transport. Their system utility is determined by the International Standard Organization (ISO) standards. International standards enable the integration of transport systems. Equipment of vehicles and infrastructure in systemic solutions is necessary for the further development of road transport. These include systems such as (www.iso.org):

- warning system informing about getting too close to the lines on the road, forcing the driver to slow down;

- systems informing about a possible collision; dedicated to vehicles moving without a driver; it is anticipated that by 2035 autonomous vehicles will be able to drive in cities;

- systems informing about the change of traffic lights, forcing the vehicle to stop by the pulse sent from the siren;

- systems regarding safe parking (parking assistant);

- systems connected with intelligent transport systems informing about accidents and traffic; mechanical vehicle problems, driver performance and response to signs of drowsiness; possibly driving beyond the current track. 
Difficulties occurring in the transport process may be problems with keeping the agreed delivery dates and processes or goods security. The weakness of Polish road transport is the high level of consumption of linear and point infrastructure, transport congestion due to the presence of the so-called bottlenecks and missing links in the transport network, lack of a coherent network of highways and "few elements of intelligent and innovative networks" (Strategy for transport development until 2020, 2013). The Polish road infrastructure, despite numerous investments and large capital expenditures, still requires development and urgent modernization on the main transport network. Technological progress and sustainable development of transport require adapting the infrastructure to the requirements of the development of electromobility and the use of alternative vehicles in commercial crossings. It seems that currently it is one of the most serious problems in the Polish road infrastructure. It is required to undertake research into the use of electric vehicles for profit and adapt the infrastructure in terms of the development of service quality.

\section{Results and discussion}

The contemporary approach to business management enforces continuous observation of the environment. In the case of transport activities, it is important to be aware of changes and the direction of the development of technical and technological instruments to improve the functioning of the sector. It seems that they are key from the perspective of shaping a competitive position on the market, efficient and effective execution of orders.

High quality of transport services is the resultant of actions undertaken by road carriers and conditions provided by the external environment. On this basis, factors that potentially influenced the quality of services were established. These factors and the results of statistical analysis are presented in Table 2.

The results of the research proved that the respondents were not unanimous about the importance of individual factors in shaping quality. The sample should be considered heterogeneous.

The most important factor in shaping quality was the ability to inform customers about the route, location of the shipment and verification of delivery time. About $42 \%$ of respondents gave the highest rating $(\mathrm{D}=6)$ to this factor. In the assessment of this factor, the highest correspondence of the response determined with the lowest value of the coefficient of variation $(\mathrm{V}=22 \%)$ and the range $(\mathrm{R}=3)$ was observed. The development of the market of road transport services changes the conditions of competition for orders. The actual time and location of the shipment currently seems to be the standard of transport services. Recognizing them as a quality attribute should be viewed positively. It can be a confirmation of market monitoring and adaptation of the offer to its needs (attempts to satisfy customer satisfaction). 
Table 2. The importance of innovation in shaping the quality of services - descriptive statistics

\begin{tabular}{|c|c|c|c|c|c|c|c|c|c|c|}
\hline Variable & $\begin{array}{l}\grave{\Xi} \\
\text { है } \\
\text { Z̆ }\end{array}$ & 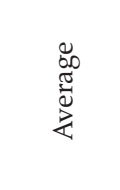 & 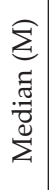 & $\begin{array}{l}\underset{\pi}{e} \\
\frac{\pi}{\delta} \\
\stackrel{0}{\Sigma}\end{array}$ & 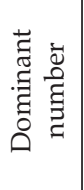 & 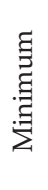 & 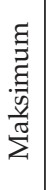 & $\begin{array}{l}\widehat{\Xi} \\
\Xi \\
\infty \\
\tilde{\Xi} \\
\approx\end{array}$ & 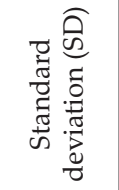 & 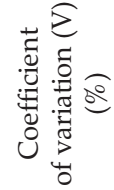 \\
\hline $\begin{array}{l}\text { Informing the customer } \\
\text { about the route, location } \\
\text { of shipments }\end{array}$ & 134 & 4.940299 & 5 & 6 & 56 & 3 & 6 & 3 & 1.095179 & 22.16827 \\
\hline Inteligent transport systems & 134 & 4.104478 & 5 & 5 & 66 & 1 & 6 & 5 & 1.165085 & 28.38571 \\
\hline Systems that improve driving & 134 & 4.104478 & 4 & 5 & 46 & 1 & 6 & 5 & 1.452344 & 35.38438 \\
\hline $\begin{array}{l}\text { Technical standards for } \\
\text { vehicles }\end{array}$ & 134 & 3.134328 & 3 & 2 & 52 & 1 & 6 & 5 & 1.284910 & 40.99474 \\
\hline $\begin{array}{l}\text { Equipment and ergonomics } \\
\text { of the driver's cab }\end{array}$ & 134 & 3.029851 & 3 & 3 & 52 & 1 & 5 & 4 & 1.136809 & 37.52031 \\
\hline Non-skid road surfaces & 134 & 2.761194 & 3 & 4 & 48 & 1 & 5 & 4 & 1.190053 & 43.09923 \\
\hline $\begin{array}{l}\text { Solar energy collectors for } \\
\text { heating asphalt }\end{array}$ & 134 & 2.358209 & 2 & 1 & 58 & 1 & 4 & 3 & 1.305874 & 55.37569 \\
\hline
\end{tabular}

Source: (based on the results of own research)

Intelligent transport systems were assessed as important $(D=5)$ in shaping quality by $50 \%$ of respondents. They were assessed mainly through the prism of systems for automatic notification of road accidents and positioning (GPS, Galileo). In respondents' opinions, they had an impact on the possibility of quick response in the event of disruptions or threats in timely execution of orders. The efficient functioning of these systems and their potential impact on transport result from the investments of the EU and individual countries. There is therefore a need to intensify actions in this area.

Intelligent transport systems determine modern infrastructure and means of transport. The ability to control traffic lights, improve the road toll payment system in EU countries, information on collisions and congestion contribute to improving the security and timeliness of services. The integration of these functions into one universal device seems to be crucial in the development and consistency of telematics and transport systems. Providing the conditions conducive to this integration at the level of the EU and individual member states is important for the quality of not only services, but also the cohesion of the European road transport system.

Solutions improving and facilitating driving were also an important element in shaping the quality of transport. The respondents' awareness in this respect should be assessed positively, despite the fact that the given rates determined the heterogeneity of the sample $(\mathrm{V}=35 \%, \mathrm{R}=5)$. About $35 \%$ of respondents rated this factor as having relevance to quality $(D=5)$. The modernity of the rolling stock is closely correlated with its innovativeness. On the other hand, the purchase of modern rolling stock, equipped with systems supporting service and managing it, can be treated as an instrument of pro-quality development. In view of the ongoing automation of work, the impact of autonomous vehicles on the quality of transport 
services seems interesting. The purchase of this type of transport means seems to be a relatively too high burden for entrepreneurs. The lack of smart infrastructure in most EU countries also does not mobilize to make investments. However, together with the creation of a system of incentives, the spread of autonomous vehicles and the development of the required infrastructure, it seems interesting to determine the impact of this type of vehicles on the safety and timeliness of deliveries.

Unexpectedly, the factors that could contribute to increased security and timeliness of deliveries in difficult weather conditions were rated low. The research results may be due to lack of experience in using modern infrastructure equipped with non-skid or heated asphalt surfaces. This constituted a conservative assessment of respondents who with reserve referred to unknown elements and infrastructural solutions. It seems that from the perspective of Polish carriers, the infrastructure equipped with a sufficient number of secure car parks, the elimination of the so-called bottlenecks on the main transport routes, intensification of the development of the TEN-T network, free access and efficient check-in at border crossings in eastern relations.

Among the factors important in shaping the quality of transport services, the equipment of the driver's cab was not included. Its ergonomic design, equipment enabling free performance of work, including taking forwarding operations and the possibility of free resting of drivers, seemed to have a significant impact on the quality of services. Comfort of drivers' work undoubtedly determines the quality of transport. Other factors not classified as important in quality issues were standards for technical vehicle parameters. The transport capacity obviously shapes the quality of services. Harmonization of technical standards at the EU level minimizes problems in providing services in international transport of goods. At this point, it is worth paying attention to the potential increase in demand for vehicles with enlarged dimensions. It can affect the conditions of competition, also inter-industry competition. Faced with measures for the greening of transport, it seems that mega trucks can increase the competitiveness of road transport against rail transport. They will also help to create a new quality of services.

Modern transport requires advanced information technologies. Road carriers using work supervision systems for drivers, vehicles, the route being travelled or fuel consumption confirmed the use of innovations in their activity. It is very cautious to assume that the respondents' awareness is rather low in terms of indirect impact on quality. Higher rates were received by factors whose implementation was the decision of carriers. The results of the research proved the need to shape carriers' awareness of the importance of innovation, the technical and technological development in the pro-quality development of operations.

\section{Conclusions}

Studies showed that the factor determining the quality of services in road transport of freight is modern infrastructure and intelligent transport systems. Construction and modernization of roads of international importance and main streams of freight should be characterized by intelligent development. Its confirmation 
is the implementation of systems facilitating quick access of competent services to the place of the road incident and its identification with information on alternative routes, traffic volume and weather conditions, etc. Intelligent infrastructure fosters punctual and safe transport processes. Decisions on the construction of a modern transport system should take into account socio-economic needs. Their quality will be an added value for all road participants in improving road safety. The development of infrastructure based on telematics systems will be conducive to the development of cabotage and cross-trade transport. Equally important is the fact that carriers perceive a qualitative development in a modern fleet equipped with systems supporting safe transport. Considering the possibility of mega trucks driving usually on designated roads, a change in the planning of transport operations will be required. An increase in the efficiency of transport and a decrease in unit costs will contribute to an increase in the demand for services with this type of vehicles. It is to be hoped that the dynamics of demand will not be higher than the rate of development of infrastructure adapted to their service.

\section{References}

Burnewicz, J. (2012), Rola państwa w kształtowaniu systemu transportowego, European Financial Congress, Sopot, https://www.efcongress.com/sites/default/files/analizy/ ekf_2012_j_burnewicz_rola-panstwa_transportowego.pdf [Accessed 28 October 2018].

Cieślik, A., Michałek, J.J. (2018), Process and product innovations, multiproduct status and export performance: firm-level evidence from V-4 countries, Equilibrium. Quarterly Journal of Economics and Economic Policy, 13(2), pp. 233-250, https://doi:10.24136/eq.2018.012.

Corral de Zubielqui, G., Lindsay, N., Lindsay, W., Jones, J. (2018), Knowledge quality, innovation and firm performance: a study of knowledge transfer in SMEs. Small Business Economics, https:// doi.org/10.1007/s11187-018-0046-0.

Garver, M.S., Williams, Z., LeMay, S.A. (2010), Measuring the importance of attributes in logistics research, The International Journal of Logistics Management, 21(1), pp. 22-44, https://doi.org/10.1108/09574091011042160.

Gea, A., Larrode, E., Millan, C. (n.d.), Analysis about quality in the freight transportation and direct effect in the management of a transportation organization, www.iasi.cnr.it/ewgt/16conference/ ID44.pdf [Accessed 24 November 2018].

Gorączkowska, J. (2018), Influence of business support organizations on innovation activity in manufacturing companies in the Masovian Voivodeship in Poland, Equilibrium. Quarterly Journal of Economics and Economic Policy, 13(4), pp. 741-759, https://doi:10.24136/ eq.2018.036.

Gronroos, Ch. (1984), A service quality model and its marketing implication, European Journal of Marketing, 18(4), pp. 36-44.

Janelle, D.G., Beuthe, M. (1997), Globalization and research issues in transportation, Journal of Transport Geography, 5(3), pp. 199-206.

Koniecny V., Stetinova, A. (2006), Quality assurance of road freight transport services, in: Michałowska, M. (Ed.), Zachowania adaptacyjne podmiotów TSL na europejskim rynku transportowym. Wydawnictwo Akademii Ekonomicznej w Katowicach, Katowice.

Kruk, H., Waśniewska, A. (2017), Application of the Perkal Method for assessing competitiveness of the countries of the Central and Eastern Europe, Oeconomia Copernicana, 8(3), pp. 337-352, https://doi: 10.24136/oc.v8i3.21.

Lazauskas, J., Bureika, G., Valiūnas, V., Pečeliūnas, R., Matijošius, J., Nagurnas, S. (2012), The research on competitiveness of road transport enterprises: Lithuanian case, Transport and Telecommunication, 13(2), pp. 138-147, https://doi:10.2478/v10244-012-0011-y. 
Melecký, L. (2018), The main achievements of the EU structural funds 2007-2013 in the EU member states: efficiency analysis of transport sector, Equilibrium. Quarterly Journal of Economics and Economic Policy, 13(2), pp. 285-306, https://doi: 10.24136/eq.2018.015.

Nijkamp, P. (2003), Globalization, international transport and the global environment: A research and policy challenge, Transportation Planning and Technology, 26(1), pp. 1-8, https://doi:10.1080/03081060309912.

Panek, T., Zwierzchowski, J. (2013), Statystyczne metody wielowymiarowej analizy porównawczej. Teoria i zastosowania, Oficyna Wydawnicza Szkoły Głównej Handlowej, Warszawa.

Parasuraman, A., Zeithaml, V.A., Berry, L. (1985), A Conceptual Model of Service Quality and Its Implications for Future Research, Journal of Marketing, 49, pp. 41-50.

Rudel, R. (2005), Evaluation of quality attributes in the freight transport market. Stated preference experiments in Switzerland, European Transport, 25-26, pp. 52-60, https://www. openstarts.units.it/bitstream/10077/5783/1/Rudel_ET25_26.pdf [Accessed 19 October 2018].

Santerre, R., Pan, L., Cai, Ch., Zhu, J. (2014), Single Point Positioning Using GPS, GLONASS and BeiDou Satellites, Positioning, 5(4), pp. 107-114, http://dx.doi.org/10.4236/ pos.2014.54013.

Spitsin, V., Mikhalchuk, A., Chistyakova, N., Spitsyna, L., Pavlova, I. (2018), Development of innovative industries in Russia under unfavourable external environment, Equilibrium. Quarterly Journal of Economics and Economic Policy, 13(3), pp. 467-485, https://doi:10.24136/ eq.2018.023.

Steer, J., Dionori, F., Casullo, L., Vollath, Ch., Frisoni, R., Carippo F., Ranghetti, D. (2013), A Review of Megatrucks. Major issues and case study, European Parliament,, Brussels, European Union, http://www.europarl.europa.eu/thinktank/en/document.html?reference $=$ IPOL-TRAN_ET(2013)513971 [Accessed 12 February 2019].

Strategia rozwoju transport do 2020 roku (z perspektywą do 2030 roku) (2013), Ministerstwo Transportu, Budownictwa i Gospodarki Morskiej, https://www.gov.pl/documents/905843/1047987/Strategia_Rozwoju_Transportu_do_2020_roku.pdf/ead3114a-aac73cdd-c71d-7f88267ce596 [Accessed 24 April 2019].

Szyc, R. (2017), Rola inteligentnych systemów transportowych w realizacji celów europejskiej polityki transportowej, Zeszyty Naukowe Wydziały Ekonomicznego Uniwersytetu Gdanskiego. Ekonomia Transportu i Logistyka, 74, pp. 423-432.

Zemlickien, V., Bublien , R., Jakubavi ius, A. (2018), A model for assessing the commercial potential of high technologies, Oeconomia Copernicana, 9(1), pp. 29-54, https://doi:10.24136/ oc.2018.002.

Zygmunt, A. (2017), Innovation activities of Polish firms. Multivariate analysis of the moderate innovator countries, Oeconomia Copernicana, 8(4), pp. 505-521, https://doi:10.24136/ oc.v8i4.31.

\section{Corresponding author}

Małgorzata Kędzior-Laskowska can be contacted at: malgorzata.kedzior@uwm.edu.pl 